\title{
Data report: no alkenones detected by shore-based GC-MS analyses of Eocene samples from Site U1356 ${ }^{1}$
}

\author{
James A.P. Bendle ${ }^{2}$ and Heiko Moossen²
}

\section{Chapter contents}

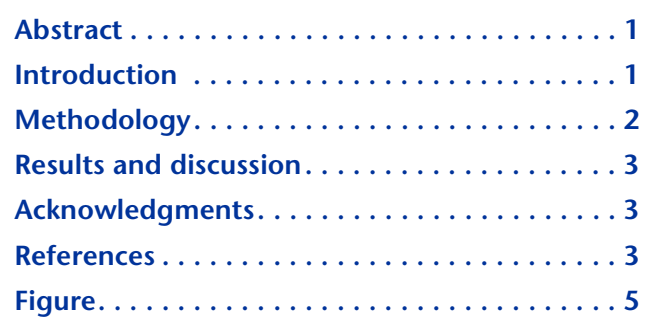

${ }^{1}$ Bendle, J.A.P., and Moossen, H., 2015. Data report: no alkenones detected by shore-based GCMS analyses of Eocene samples from Site U1356. In Escutia, C., Brinkhuis, H., Klaus, A., and the Expedition 318 Scientists, Proceedings of the Integrated Ocean Drilling Program, 318: Tokyo (Integrated Ocean Drilling Program Management International, Inc.).

doi:10.2204/iodp.proc.318.203.2015

${ }^{2}$ Birmingham Molecular Climatology Laboratory (BMC), School of Geography, Earth and Environmental Science, University of Birmingham, Edgbaston, Birmingham B15 2TT, United Kingdom. Correspondence author:

j.bendle@bham.ac.uk

\section{Abstract}

We applied shore-based gas chromatography-mass spectrometry (GC-MS) to confirm shipboard analyses of samples from Integrated Ocean Drilling Program (IODP) Expedition 318. Initially, 25 samples from Site U1356, ranging in age from early Eocene to late Miocene, were extracted for lipids, separated into chemical fractions, and analyzed by GC-MS onboard the R/V JOIDES Resolution. Molecular biomarker classes identified include aliphatic hydrocarbons, hopanes, unresolved complex mixtures of branched alkanes, ketones, $n$-alkanols, sterols, diols, and $n$-alkanoic acid methyl esters. Relative to the Oligocene and Miocene, molecular concentrations generally increase by several orders of magnitude in the early Eocene sediments. Additional shore-based analyses confirmed the presence of a diverse range of terrestrial biomarkers that includes plant-waxes and hopanes. However, additional analysis of the ketone fraction from 50 Eocene samples from Site U1356 detected no alkenone compounds. This negative result supersedes the initial report of alkenones in the Eocene sediments from Site U1356 and indicates that shipboard assignation of alkenones was erroneous.

\section{Introduction}

Integrated Ocean Drilling Program (IODP) Expedition 318 to the Wilkes Land margin of Antarctica recovered a sedimentary succession ranging in age from the early Eocene to the Holocene. Site U1356 is at the transition between the continental rise and the abyssal plain at 4003 meters below sea level (mbsl) and was cored to 1006.4 meters below seafloor (mbsf) (see Figure F16 in the "Site U1356" chapter [Expedition 318 Scientists, 2011b]). The sediments are divided into 11 lithostratigraphic units, and age control is based on biostratigraphic datums from siliceous microfossils (diatoms and radiolarians), calcareous nannofossils, and organicwalled dinoflagellates (dinocysts) integrated with a magnetostratigraphy that is correlated, where feasible, to the geomagnetic polarity timescale (GPTS) (Tauxe et al., 2012). This data report is concerned with samples from the lowermost $110 \mathrm{~m}$ of Site U1356 (lithostratigraphic Units X and XI), dated to the early to middle Eocene (53.6-46 Ma) with a hiatus from 51.9 to $49.3 \mathrm{Ma}$ (Tauxe et al., 2012). Unit X (Cores 318-U1356A-96R through 100R; 895.5$948.8 \mathrm{mbsf}$ ) consists of interbedded stratified and massive sand- 
stones, diamictites, silty claystones, and siltstones. Unit XI (Cores 101R to 106R; 948.8-1000.08 mbsf) consists predominantly of dark green bioturbated claystone and subordinate laminated siltstone and sandstone interbeds (see the "Site U1356" chapter [Expedition 318 Scientists, 2011b]). During the Eocene, Site U1356 was at a latitude of $\sim 65^{\circ} \mathrm{S}$, and the dinocyst assemblages suggest a midshelf depositional environment much shallower than today (Pross et al., 2012).

Shore-based analyses of biotic climate proxies (pollen and spores) and indexes based on branched tetraether lipids reveals that the climate in lowland settings along the Wilkes Land coast in the early Eocene (Unit XI) supported the growth of highly diverse, near-tropical forests characterized by mesothermal to megathermal floral elements with extremely mild terrestrial winters $\left(>10^{\circ} \mathrm{C}\right)$ (Pross et al., 2012), while sea-surface temperatures were extremely warm (Bijl et al., 2013). The middle Eocene (Unit X) is characterized by a marked sea-surface temperature and continental cooling $\left(2^{\circ}-4^{\circ} \mathrm{C}\right)$ (Bijl et al., 2013), loss of megathermal flora, and dominance of a temperate rain forest assemblage (Pross et al., 2012). Furthermore, ongoing work on biomarkers from Site U1356 confirms the presence of the bacterial-derived, $\mathrm{C}_{31}$ $(17 \alpha, 21 \beta)$ homohopane within a suite of immature hopanes. The timing of the concentration fluctuations and the molecular structure of hopanes and their compound-specific carbon isotope values $\left(\delta^{13} \mathrm{C}\right)$ reveal the extent to which wetlands fluctuated in response to external, orbital forcing (Toney et al., 2012).

The initial report of alkenones in the Eocene sediments of Site U1356 was significant because alkenones can be utilized both for paleotemperature estimation (e.g., Conte et al., 2006; Prahl and Wakeham, 1987) and as a proxy for the estimation of past $p \mathrm{CO}_{2}$ levels (e.g., Zhang et al., 2013). Thus, we undertook shore-based analysis of 50 samples from Site U1356 to confirm the initial report of the presence of alkenones and to assess whether sufficient concentrations were present for compound-specific $\delta^{13} \mathrm{C}$ measurements.

\section{Methodology}

\section{Shipboard}

Amenable lipids were extracted using a method adapted from Bendle et al. (2007). Full details are given in the "Methods" chapter [Expedition 318 Scientists, 2011a; also see Figure F19 in that chapter]. In brief, sediments were freeze-dried and homogenized, and 2-20 g was hydrolyzed and extracted. The total lipid extract was separated into discrete chemical fractions using methods adapted from Bendle et al. (2007): aliphatic hydrocarbons $/ n$-alkanes (N1), aromatic hydrocarbons (N2), aldehydes and ketones (N3), and alcohols (N4). Alcohols in fraction N4 were derivatized to trimethylsilyl ethers using bis(trimethylsilyl)trifluoroacetamide (BSTFA) reagent. Acidic components were extracted with methylene chloride from the remaining solution after acidifying $(\mathrm{pH}=1)$ with $\mathrm{HCl}$. The acidic fraction was concentrated and the carboxylic acids were derivatized to methyl esters with $14 \% \quad \mathrm{BF}_{3} /$ methanol $(\mathrm{MeOH})$. The individual lipid fractions were analyzed, and structural identification was confirmed using an HP 5973 gas chromatography mass spectrometer (GC-MS) equipped with a 7683 autosampler and fused silica capillary column (DB-1 $60 \mathrm{~m} \times$ $0.317 \mathrm{~mm}$; internal diameter $\times 1.50 \mu \mathrm{m})$ and mass selective detector (MSD). The GC oven temperature was programmed to ramp at $30^{\circ} \mathrm{C} / \mathrm{min}$ from $50^{\circ}$ to $120^{\circ} \mathrm{C}$ and then ramp at $5^{\circ} \mathrm{C} / \mathrm{min}$ to $300^{\circ} \mathrm{C}$, with a final hold time of $22 \mathrm{~min}$.

\section{Shore-based extraction and clean-up}

Organic compounds were extracted from 100 powdered and freeze-dried sediment samples at the Royal Netherlands Institute for Sea Research (NIOZ; Utrecht University, Netherlands), and the University of Glasgow (Scotland, United Kingdom) using methods described by Pross et al. (2012). Lipids were extracted by dichloromethane (DCM)/MeOH $(9: 1, \mathrm{v} / \mathrm{v})$ using the an accelerated solvent extractor (Dionex). The total lipid extract was separated into apolar, ketone, ethyl acetate (EtOAc), and polar fractions over an activated $\mathrm{Al}_{2} \mathrm{O}_{3}$ column using hexane: DCM (9:1, v/v), hexane:DCM (1:1, v/v), EtOAc:DCM (1:1 v/v), and DCM:MeOH $(1: 1, \mathrm{v} / \mathrm{v})$, respectively.

\section{Ketone fraction GC-MS analyses}

Fifty ketone fraction samples (every other downcore sample from the 100 shore-based extractions) were analyzed using an Agilent GC 7890B coupled to a 5977A MSD GC-MS and equipped with a 7693 autosampler and fused silica capillary column (BP-1 $60 \mathrm{~m}$ $\times 0.25 \mathrm{~mm}$ internal diameter $\times 0.25 \mu \mathrm{m})$ and mass selective detector at the Birmingham Molecular Climatology Laboratory. The GC oven temperature was programmed to hold for $1 \mathrm{~min}$ at $60^{\circ} \mathrm{C}$, ramp at $30^{\circ} \mathrm{C} / \mathrm{min}$ from $60^{\circ}$ to $130^{\circ} \mathrm{C}$ and then ramp at $3^{\circ} \mathrm{C} / \mathrm{min}$ to $345^{\circ} \mathrm{C}$, with a final hold time of $15 \mathrm{~min}$. The interface temperature was $340^{\circ} \mathrm{C}$. The detector was operated in electron impact mode, scanning from 50 to $800 \mathrm{~m} / \mathrm{z}$. 


\section{Results and discussion}

At Site U1356, 25 samples ranging in age from early Eocene to late Miocene were extracted for lipids, separated into chemical fractions, and analyzed by GCMS onboard the R/V JOIDES Resolution. The compound classes reported include aliphatic hydrocarbons, hopanes, unresolved complex mixtures of branched alkanes, ketones, $n$-alkanols, sterols, diols, and $n$-alkanoic acid methyl esters (FAMES). Relative to the Oligocene and Miocene, molecular concentrations generally increase by several orders of magnitude in the early Eocene sediments. The N1, N3, N4, and FAMES fractions were analyzed by GC-MS, and the results from each fraction are summarized in Tables T10, T11, T12, and T13 in the "Site U1356" chapter [Expedition 318 Scientists, 2011b]), respectively (the N2 and N5 fractions were archived). Examples of GC-MS total- and single-ion chromatograms (of the four analyzed fractions) from four samples are presented in Figures F23 (middle Miocene), F24 (late Oligocene), F25, and F26 (both early Eocene) in the "Site U1356" chapter [Expedition 318 Scientists, 2011b]).

Shipboard analysis revealed a grouping of three to four peaks eluting late in the ketone fraction (N3) in $>50 \%$ of the samples. No alkenone standards were available on ship for comparison. However, based on the general retention time and distribution, these peaks superficially suggested a distribution similar to that expected for the $\mathrm{C}_{37: 2}, \mathrm{C}_{38: 2}$, and $\mathrm{C}_{39: 2}$ alkenones. The detector response of these late-eluting peaks was weak when analyzed by the shipboard GC-MS in "scanning mode," and the resultant mass spectra were inconclusive. However, the late-eluting peaks appeared more prominent when analyzed in "single ion monitoring" (SIM) mode for a number of individual, characteristic mass fragments associated with alkenones (e.g., $\mathrm{m} / \mathrm{z} 81,109$ ). Thus, the initial shipboard assignation of alkenones was made (see Figs. F25 and F26 and Table T11 in the "Site U1356" chapter [Expedition 318 Scientists, 2011b]).

The additional 50 ketone fraction samples taken from throughout the lowermost $110 \mathrm{~m}$ (Units X and XI) of Site U1356 were analyzed on shore to assay for alkenone compounds and confirm the shipboard analyses. As with the shipboard analyses, a grouping of three to four peaks eluted late in the ketone fraction in the majority of the samples. However, the mass spectra of the late-eluting analytes, as produced by shore-based GC-MS, do not show any diagnostic similarity with known alkenone compounds. Shorebased GC-MS results from a representative sample from Site U1356 are given in Figure F1A. For com- parison, an alkenone-yielding, Quaternary age sample from the Japan Sea was analyzed in the same laboratory, using the same GC-MS, under the same temperature program and conditions. Figure F1B confirms that positive alkenone identification using the shore-based GC-MS and conditions was feasible, with mass spectra exhibiting characteristic alkenone fragmentation patterns. Moreover, comparison of Figures F1A and F1B unambiguously indicates that the late-eluting peaks in the Site U1356 samples are not alkenones on the basis of both peak retention time and mass spectra. This negative result supersedes the initial report of alkenones in the Eocene sediments of Site U1356 and indicates that shipboard assignation of alkenones was erroneous.

\section{Acknowledgments}

This research used samples and data provided by the Integrated Ocean Drilling Program (IODP). The IODP is sponsored by the US National Science Foundation and participating countries under the management of IODP Management International, Inc. We thank IODP Expedition 318 party members, IODP, and the IODP Gulf Coast Repository (GCR). Financial support for this research was provided by the Netherlands Organisation for Scientific Research, to Professor Stefan Schouten (VICI grant); the Natural Environment Research Council, to J.A. Bendle (grant $\mathrm{Ne} / \mathrm{I00646X/1).} \mathrm{We} \mathrm{thank} \mathrm{Simon} \mathrm{Brassell,} \mathrm{Prof.} \mathrm{Ste-}$ fan Schouten, and Dr. Peter Bijl for discussions and feedback related to this report and technical staff at NIOZ, Utrecht, and Glasgow and Frederike Wittkopp (Birmingham University [United Kingdom] Ph.D. student) for support in producing data. We acknowledge Kara Bogus for a constructive review of the submitted manuscript.

\section{References}

Bendle, J., Kawamura, K., Yamazaki, K., and Niwai, T., 2007. Latitudinal distribution of terrestrial lipid biomarkers and $n$-alkane compound-specific stable carbon isotope ratios in the atmosphere over the western Pacific and Southern Ocean. Geochimica et Cosmochimica Acta, 71(24):5934-5955.

http://dx.doi.org/10.1016/j.gca.2007.09.029

Bijl, P.K., Bendle, J.A.P., Bohaty, S.M., Pross, J., Schouten, S., Tauxe, L., Stickley, C.E., McKay, R.M., Röhl, U., Olney, M., Sluijs, A., Escutia, C., Brinkhuis, H., and Expedition 318 Scientists, 2013. Eocene cooling linked to early flow across the Tasmanian Gateway. Proceedings of the National Academy of Sciences of the United States of America, 110(24):9645-9650.

http://dx.doi.org/10.1073/pnas.1220872110 
Conte, M.H., Sicre, M.-A., Rühlemann, C., Weber, J.C., Schulte, S., Schulz-Bull, D., and Blanz, T., 2006. Global temperature calibration of the alkenone unsaturation index $\left(\mathrm{UK}^{\prime}{ }_{37}\right)$ in surface waters and comparison with surface sediments. Geochemistry, Geophysics, Geosystems, 7(2):Q02005.

http://dx.doi.org/10.1029/2005GC001054

Expedition 318 Scientists, 2011a. Methods. In Escutia, C., Brinkhuis, H., Klaus, A., and the Expedition 318 Scientists, Proceedings of the Integrated Ocean Drilling Program, 318: Tokyo (Integrated Ocean Drilling Program Management International, Inc.).

http://dx.doi.org/10.2204/iodp.proc.318.102.2011

Expedition 318 Scientists, 2011b. Site U1356. In Escutia, C., Brinkhuis, H., Klaus, A., and the Expedition 318 Scientists, Proceedings of the Integrated Ocean Drilling Program, 318: Tokyo (Integrated Ocean Drilling Program Management International, Inc.).

http://dx.doi.org/10.2204/iodp.proc.318.104.2011

Prahl, F.G., and Wakeham, S.G., 1987. Calibration of unsaturation patterns in long-chain ketone compositions for paleotemperature assessment. Nature, 330(6146):367-369.

http://dx.doi.org/10.1038/330367a0

Pross, J., Contreras, L., Bijl, P.K., Greenwood, D.R., Bohaty, S.M., Schouten, S., Bendle, J.A., Röhl, U., Tauxe, L., Raine, J.I., Huck, C.E., van de Flierdt, T., Jamieson, S.S.R., Stickley, C.E., van de Schootbrugge, B., Escutia, C., Brinkhuis, H., and Integrated Ocean Drilling Program Expedition 318 Scientists, 2012. Persistent neartropical warmth on the Antarctic continent during the early Eocene epoch. Nature, 488(7409):73-77.

http://dx.doi.org/10.1038/nature11300
Tauxe, L., Stickley, C.E., Sugisaki, S., Bijl, P.K., Bohaty, S.M., Brinkhuis, H., Escutia, C., Flores, J.A., Houben, A.J.P., Iwai, M., Jiménez-Espejo, F., McKay, R., Passchier, S., Pross, J., Riesselman, C.R., Röhl, U., Sangiorgi, F., Welsh, K., Klaus, A., Fehr, A., Bendle, J.A.P., Dunbar, R., Gonzàlez, J., Hayden, T., Katsuki, K., Olney, M.P., Pekar, S.F., Shrivastava, P.K., van de Flierdt, T., Williams, T., and Yamane, M., 2012. Chronostratigraphic framework for the IODP Expedition 318 cores from the Wilkes Land Margin: constraints for paleoceanographic reconstruction. Paleoceanography, 27(2):PA2214. http://dx.doi.org/10.1029/2012PA002308

Toney, J.L., Bendle, J.A., Seki, O., Krishnan, S., Pagani, M., Inglis, G., Pancost, R., Bijl, P.K., Bohaty, S., Schouten, S., Pross, J., Brinkhuis, H., Roehl, U., Jamieson, S., and the IODP Expedition 318 Team, 2012. Insights into peatland expansion and methane cycling on the East Antarctic continent in the early Eocene. Geophysical Research Abstracts, 14:EGU2012-8210. http://meetingorganizer.copernicus.org/EGU2012/EGU20128210.pdf

Zhang, Y.G., Pagani, M., Liu, Z., Bohaty, S.M., and DeConto, R., 2013. A 40-million-year history of atmospheric $\mathrm{CO}_{2}$. Philosophical Transactions of the Royal Society, A: Mathematical, Physical \& Engineering Sciences, 371(2001):1-20.

http://dx.doi.org/10.1098/rsta.2013.0096

Initial receipt: 25 February 2015

Acceptance: 19 October 2015

Publication: 11 December 2015

MS 318-203 
Figure F1. A. Total ion chromatogram of the ketone fraction of an early Eocene sample (318-U1356A-103R-4, 78-77 cm). B. Total ion chromatogram of the ketone fraction of a sample collected from Quaternary sediments from IODP Hole U1425B, Japan Sea. The suites of $\mathrm{C}_{37}, \mathrm{C}_{38}$, and $\mathrm{C}_{39}$ alkenones are indicated (number in subscript denotes chain length). The molecular structures, specific identifications, and full IUPAC nomenclature are given for the $\mathrm{C}_{37: 2}$ and $\mathrm{C}_{37: 3}$ alkenones. Additionally, the electron impact mass spectrogram for the $\mathrm{C}_{37: 2}$ alkenone is illustrated. See text for details on compound identifications.

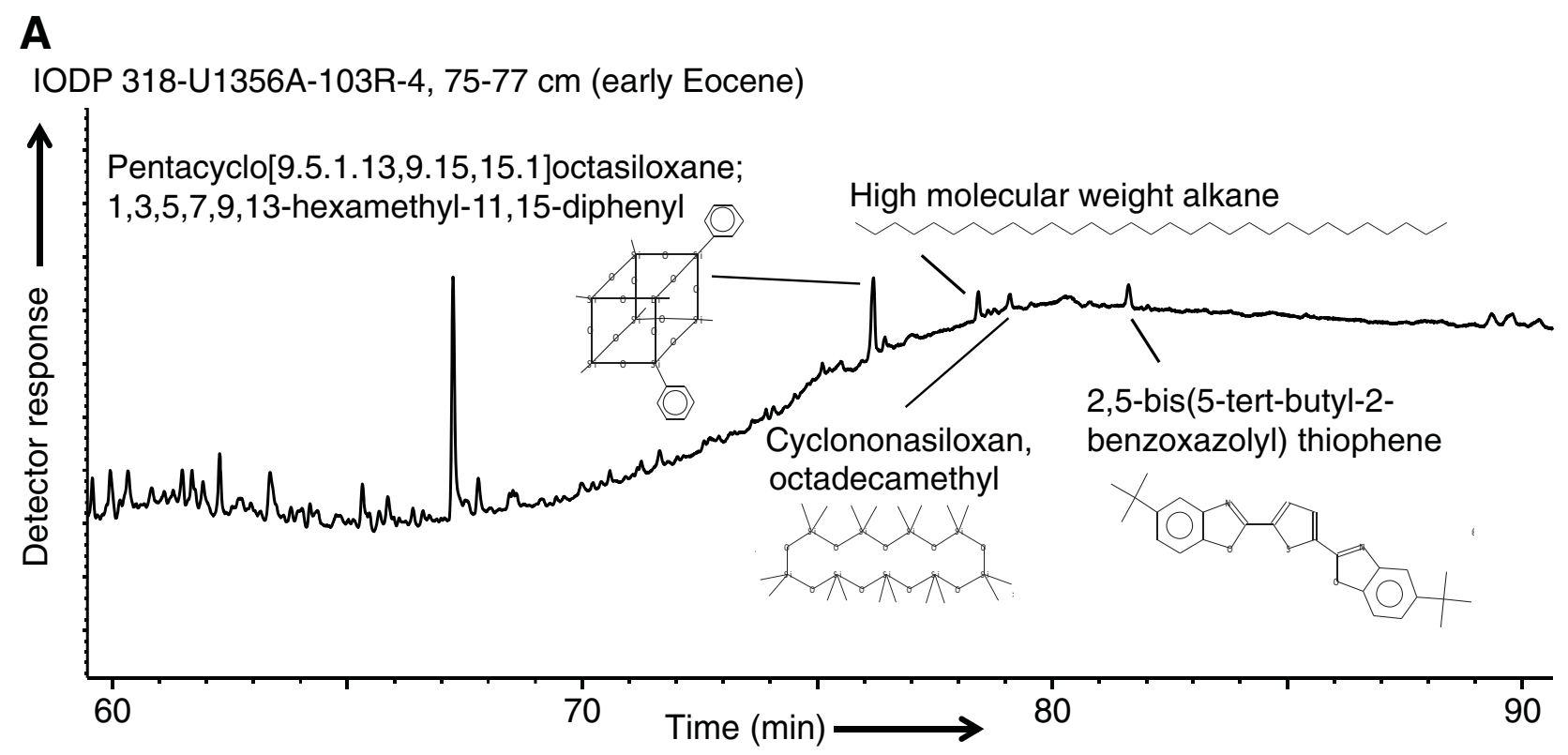

B

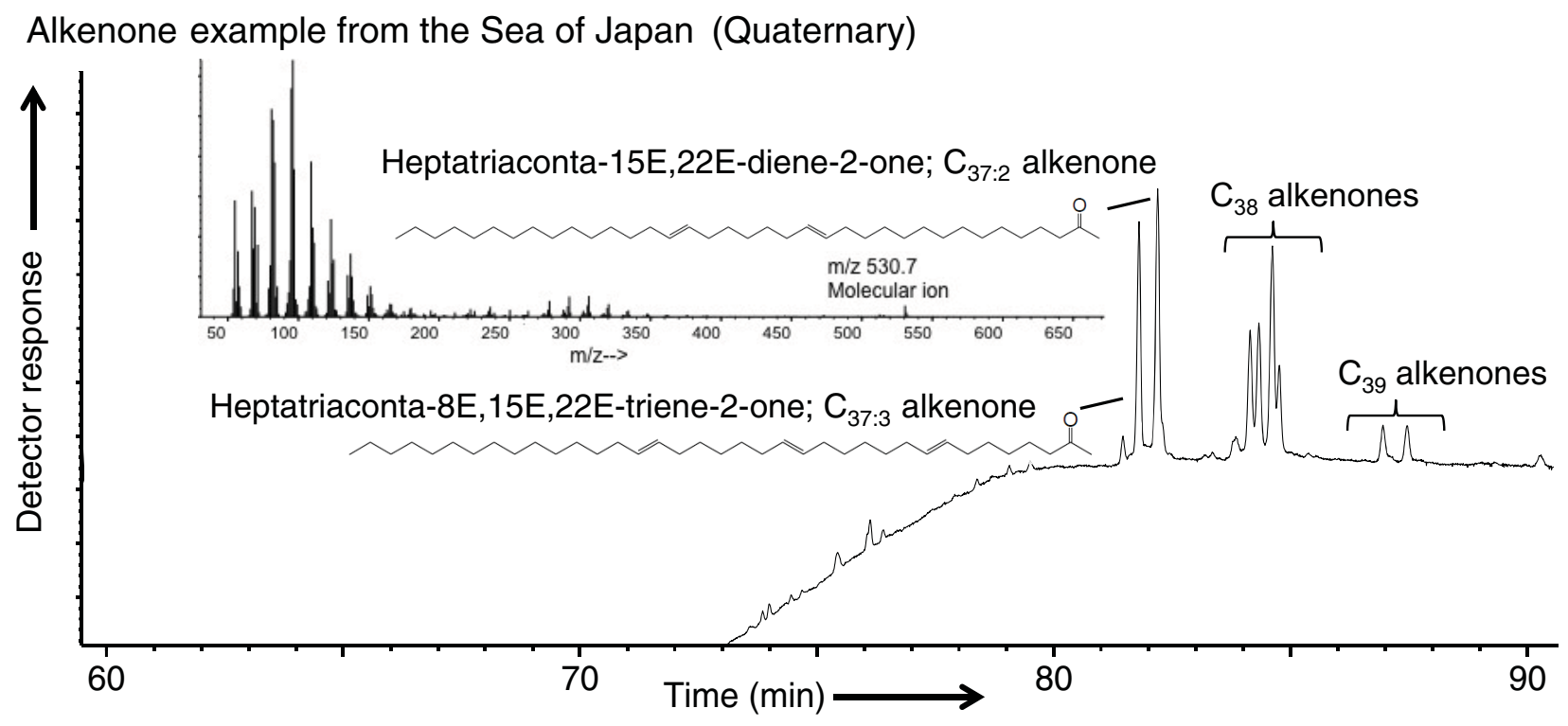

